\title{
Distribution of Siliceous-Walled Algae in Taylor Valley, Antarctica Lakes
}

\author{
Jonathan P. Warnock ${ }^{*}$, Peter T. Doran \\ Department of Earth and Environmental Sciences, University of Illinois, Chicago, USA \\ Email: ${ }^{*}$ jonathanpwarnock@gmail. com
}

Received April 12, 2013; revised May 14, 2013; accepted June 13, 2013

Copyright (C) 2013 Jonathan P. Warnock, Peter T. Doran. This is an open access article distributed under the Creative Commons Attribution License, which permits unrestricted use, distribution, and reproduction in any medium, provided the original work is properly cited.

\begin{abstract}
The McMurdo Dry Valleys of Antarctica are a unique environment characterized by extreme lows in temperature and precipitation, which supports a low diversity microbial and multicellular fauna and flora. Terrestrial biomass is largely limited to soil microbes and mosses, while perennially ice-covered lakes host aerobic and anaerobic microbial communities, algae, and a low diversity eukaryotic fauna. This study provides a scanning electron microscope survey of the distribution of siliceous-walled algae in the water columns and surface sediments of four Taylor Valley lakes. No patterns of distribution of algae, chrysophyte cysts and diatoms, are detected, suggesting that cores taken from perennially ice-covered lakes contain basin-wide records, rather than records specific to the lake depth or other lake-specific criteria. Since Taylor Valley lakes became perennially ice-covered, shifts in diatom assemblages in cores are more likely to record changes to sediment and microfossil transport, e.g. the dominance of eolian vs. stream input, rather than other ecological conditions. Basin-wide records are episodically overprinted by lake-specific events, as demonstrated by a marked increase of the stream diatom genus Hantzschia during a period of increased stream flow into East Lake Bonney.
\end{abstract}

Keywords: Modern Analogues; Antarctic Diatoms; Perennially Ice-Covered Lakes; Resource Legacy; Paleolimnology

\section{Introduction}

The McMurdo Dry Valleys (MDV's) of Antarctica comprise a unique environment maintained by extreme cold and low levels of precipitation [1]. The presence of an ancient nutrient pool, an "ecological legacy", allows for increased primary production relative to that expected in a cold, low precipitation environment [2]. Ice covered lakes provide the only ecosystems in the Dry Valleys that are wet year round and therefore capable of uninterrupted biological activity, making them areas of high interest. Resource distribution within the lakes is not uniform, and each nutrient input source (stream, glacial, and eolian) has a unique distribution.

Streams contain a higher microbial diversity and higher amounts of organic material than soil communities [3]. Stream water is dominantly composed of glacial melt, but is also made up of soil-bound ice melt with associated organic matter and sparse meteoric water. It has been documented that where streams enter the lakes,

\footnotetext{
${ }^{*}$ Corresponding author.
}

sedimentary material can be transported under the ice to a lateral distance of at least $6 \mathrm{~m}$ from the moat/ice interface [4]. Where glaciers terminate at lake edges, glacial water, nutrients, and sediment is direcly deposited into lakes. Eolian sediment and nutrients blanket Dry Valley lakes. This wind-blow material is deposited in all lake regions, and is the only material to reach deep benthic habitats, planktonic areas away from moats, and within ice habitats. Soils and streams in TV are nearly continuously dry; therefore eolian material mixes glacial, stream, and soil nutrient sources. It could be hypothesized that algal communities within Dry Valley lakes could be predicted based on the amounts of each input source feeding nutrients to any given location in the lake. In this paper we describe the distribution of diatoms and chrysophyte cysts in four lakes in Taylor Valley, Antarctica. No patterns of distribution of siliceous-walled algae are identified within or between lakes.

Legacy effects control the distribution of nutrients in the McMurdo Dry Valleys [2]. An understanding of modern conditions and processes is impossible without an 
understanding of past events [2]. The Dry Valleys were largely unglaciated during the last glacial maximum (LGM), allowing for the formation and maintenance of an ecosystem with habitats similar to the modern, i.e. with streams, lakes, and exposed soils [5]. The damming ofthe mouth of Taylor Valley as the Ross Ice Sheet retreated following the LGM resulted in the formation of a large, proglacial lake, Glacial Lake Washburn (GLW) [6, 7]. Gradually, through a series of high and low stands, GLW was drawn down to below present levels, thereby abandoning lacustrine organic matter (OM) and solutes on the walls of TV and concentrating OM and solutes into small brine ponds in the low points of TV-the precursors to the present TV lakes $[2,5,8]$. It is predicted that modern life in Taylor Valley would be greatly limited without this reservoir [2,9].

TV lakes are perennially covered by three to six meters of ice resulting inpersistent stratification of the lake water [10]. Each of these lakes is present in a closed basinand is fed by glacial melt via ephemeral streams during the austral summer. With the exception of freshwater Lake Hoare, each of the lakes has a stratified water columncomposed of a fresh upper layer and saline deep water [10]. Seasonal ice melt forms moats during the austral summer [11]. Moat deposits are formed by sediment input from both eolian and stream sources. Eolian material, containing live bacteria and diatoms [12], deposited onto the ice cover of Taylor Valley lakes, is transported downward through the ice to form mounds and ridges on lake bottoms [13], giving the lake bottom landscape a high level of topographic heterogeneity and providing a nutrient input source separate from glacial melt.

Primary production in benthic organic matter (BOM) of dry valley lakes is carried out by photosynthetic bacteria and diatoms within benthic microbial mats $[14,15]$. The relative abundance and distribution of these organisms in the lakes are largely unknown; however, Spaulding et al. [16] reported on the diatom flora contained within sediment cores collected from Lakes Hoare and Fryxell. Sedimentation through the perennial ice cover results in frequent recolonization of benthic mats [13], and transports diatoms to into anoxic environments [16]. Primary productivity in the water column is fueled by recycling of legacy nutrients from below, and from the input of eolian and stream OM from above. Organic matter, in the form of microbial mats, is also transported out of the lakes by upward movement through the ice cover [17]. Such movement is caused by ablation at the ice surface and addition of new ice at the ice/water interface [17]. The annual flux from the upper to lower water column is an order of magnitude greater than the flux in the reverse direction [18]. Therefore, more organic matter moves from the soils into the lakes than moves out of the lakes into the soils, an idea supported by the ecological legacy model [2].

\section{Methods}

Four basins were sampled in Taylor Valley: Fryxell, Hoare, and East and West Bonney (Figure 1). The samples used for this study were collected for the study by Lawson et al. [4]. A detailed description of collection methods can be found there. In brief, materials were collected over three Antarctic summers (November to January, 1999-2002). The first two field seasons are referred to as non-flood years. The final field season, 2001/2002, is referred to as a flood year: moats were estimated to be 3 - 4 times larger than in previous years, lake levels rose $\sim 1 \mathrm{~m}$, and the total flow of all gauged streams showed a fivefold increase [4,16]. Large Mark 78H-21 PARFLUX time series sediment traps (McLane Research), poisoned with benzalkonium chloride $(<5 \mathrm{mg} / \mathrm{L})$, were deployed at $35 \mathrm{~m}$ depths in the deep basin centers of both lobes of Lake Bonney in December, 2000 and recovered after one year.

Moat and benthic organic matter (BOM) sampling was done during the 2000/2001 season. During the flood year (2001/2002), stream proximal (SP, where a stream entered the moat) and stream distal (SD, no stream present at sampling location) depth profiles were sampled for particulate organic matter (POM), which was filtered on precombusted $47 \mathrm{~mm}$ Whatman $\mathrm{GF} / \mathrm{F}$ fiberglass filters. Unfortunately, amounts of water sampled and sediment captured varied highly. Additionally, the sediment was ground after drying on the filter. These sampling methods make absolute abundance counts for diatoms and chrysophyte cysts impossible. Furthermore, relative abundances between samples are not robust. For these

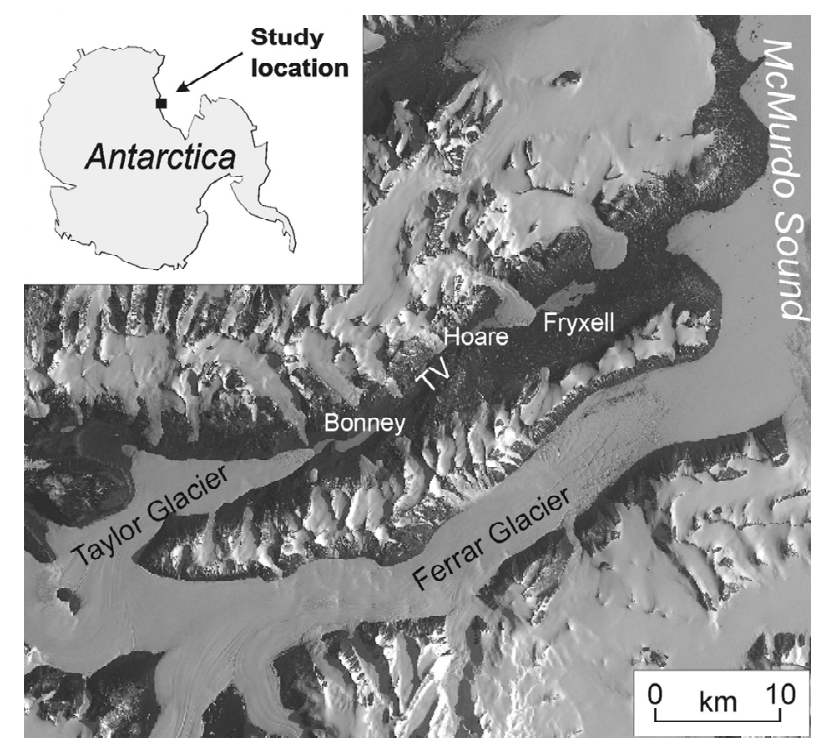

Figure 1. Map of Taylor Valley (TV), showing the location of all sampled lakes. North is towards the top of the page. 
reasons, numerical data are not present. Qualitative relative abundances as well as presence/absence data are used to characterize samples.

Lawson's loose sediment was subsampled (1 - 2 g) into unused glass vials with $5-10 \mathrm{ml}$ of de-ionized water. The resulting slurry was plated onto $12 \mathrm{~mm}$ diameter round glass slides and dried. These were affixed to $9 \mathrm{~mm}$ diameter stubs for SEM viewing with carbon paint and gold coated (500 $\AA$ ) in a Denton Vacuum Desk II sputter coater. POM filters, where still were available, were cut with a $9 \mathrm{~mm}$ diameter boring tool and affixed to $9 \mathrm{~mm}$ stubs with carbon paint and sputter coated. The boring tool was cleaned between cuttings; no stubs were reused. It is important to note that the amount of material used between samples was not able to be held constant. The thickness of sediment on each filter was highly variable, and it was not possible to remove all sediment from the filters. While presence/absence data will not be affected by this, relative abundances are highly subjective. All SEM analyses were done on a JEOL 5610LV SEM or JEOL 5600LV SEM under high vacuum. SEM was chosen for precision in identification to the species level for diatoms and to differential chrysophyte cysts.

All diatoms and chrysophyte cysts were imaged. Sample images are included, however an image of each observed species is not included (Figure 2). After each object was imaged, a "map" image was taken at $300 \times$ magnification. The map was used to assess relative abundance and provide a context for each valve or cyst. Diatoms were identified to the species level on the basis of morphology according to the McMurdo LTER website (http://huey.colorado.edu/diatoms/about/index.php) and references contained therein. Chrysophyte cysts were categorized on the basis of morphology. Not all cysts could be linked to a previously described morphotype $[19,20]$. Other single and multicellular life was found, but not

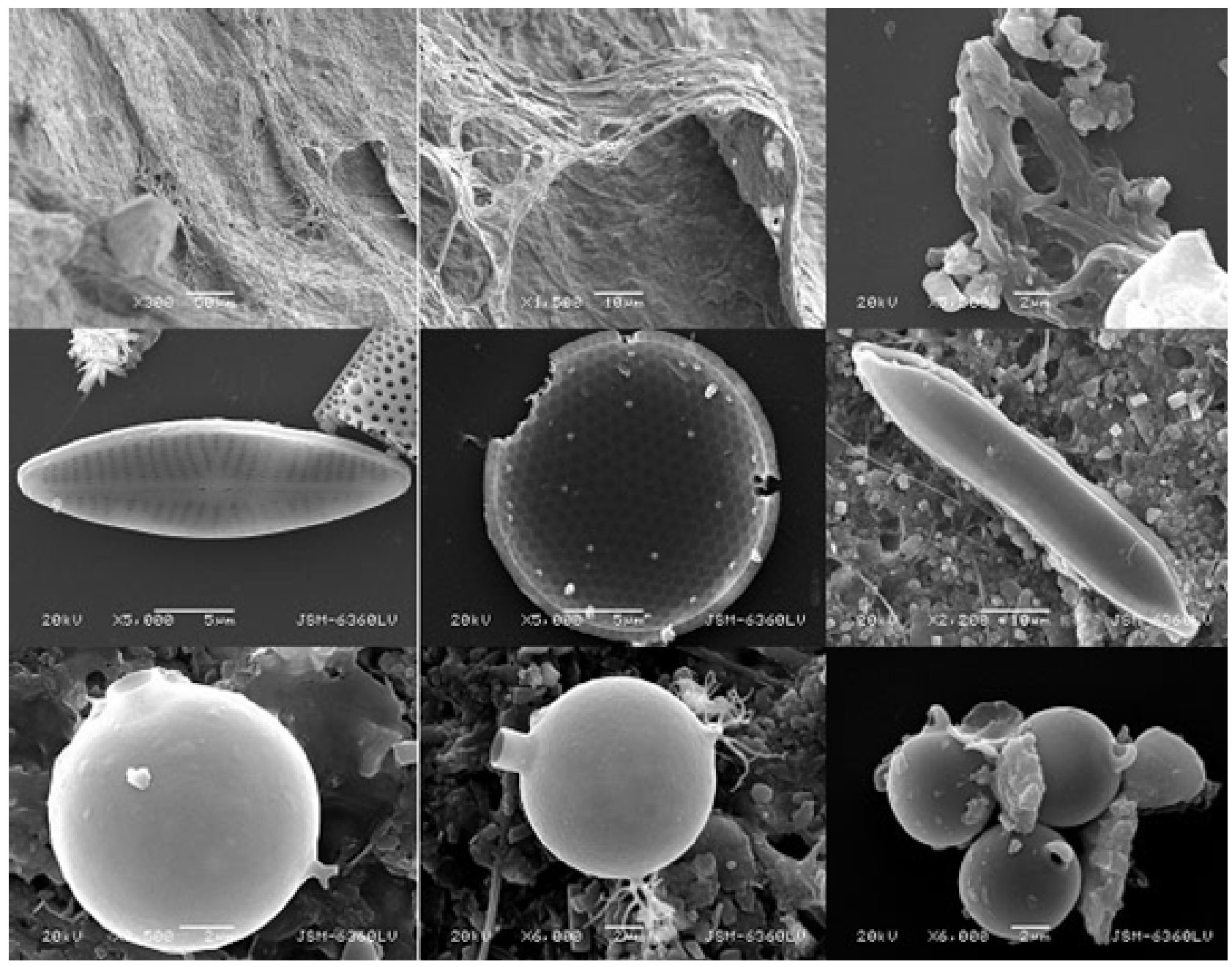

Figure 2. Example images. These are selected images of (top to bottom) bacterial mat and fibers, diatoms, and chrysophytes. Top row, left to right, Lake Chad lift off mat, same section of mat at higher magnification, fragmentary fibers from benthic organic matter.Middle row, Naviculacincta, the marine diatom Melosiracharcotii, Hantzschiaabundans. Bottom row, Chrysophyte cyst 4 , cyst 5 , cyst 1 . Not all species and morphotypes identified are shown. Scale bars are individually labeled. 
included in this analysis.

\section{Results}

Biological material was found in all samples, however some POM samples contained only bacteria, and no diatoms or chrysophyte cysts. Diatoms were found as individual valves, whole frustules, and colonial chains. Fragmentary valves were likely transported, while whole frustules and especially chains imply in situ growth. Cytoplasm was frequently found associated with diatom frustules, indicating that diatom transport is an important component of nutrient cycling in TV lakes. Cytoplasm was not found associated with chrysophyte cysts, making it difficult to visually determine whether or not transport had occurred. However, only one area (ELB BOM and sediment trap material) contained chrysophyte cysts in ecologically significant numbers (e.g. more than two per sample).

\subsection{Lake Fryxell}

The biotic composition of each of the samples from LF is shown in Table $\mathbf{1}$ and illustrated on Figures $\mathbf{3}$ and $\mathbf{4}$. POM is rare in the water column of LF; only the moat SP sample contained freshwater diatoms. These diatoms are stream-associated species from the genera Hantzschia and Navicula. Some marine diatoms were found deeper in the water column. Within the BOM, diatoms are found in all SP samples and at $6.4 \mathrm{~m}$. These samples are more diverse and abundant than the POM, but contain species cosmopolitan to TV. No diatoms are found in the deeper or stream distal samples. Only a single chrysophyte cyst was found in LF.

\subsection{Lake Hoare}

Results for Lake Hoare (LH) are shown in Table 2 and illustrated on Figures 3 and 4.

Diatoms are found in all samples, except for moat BOM. POM samples contain stream-associated genera not found in the BOM. Only one species (Naviculagregaria) is found throughout the BOM, however it is completely absent from the POM. Most diatom species are common to both sample types, but some (Diadesmiscontenta, Muelleriaperaustralis) occur most in POM and others (Luticolagausii, Pinnulariadeltaica, Psammothidiumchlidanos) occur most in BOM. Only two individual chrysophyte cysts were found in $\mathrm{LH}$.

\subsection{East Lake Bonney}

The biota observed within East Lake Bonney (ELB) are shown in Table $\mathbf{3}$ and illustrated on Figures $\mathbf{3}$ and $\mathbf{4}$. ELB is similar to $\mathrm{LH}$ in that both have abundant diatoms. In contrast to $\mathrm{LH}$ and LF, siliceous-walled algae are more common in the POM than BOM. Diatoms are found in every sample, except for BOM $37.5 \mathrm{~m}$. They are most abundant and diverse in the POM. One diatom, Hantzschiaamphioxys, is a common wet soil diatom associated with hyporeic zones on stream margins. It is found in abundance in the POM throughout the water column. The ecological associations, preference for water column or sediment, seen between diatoms in LH are not found in ELB. Diatom species found in the SP samples are also found in the shallowest under-ice POM. Marine diatom fragments are also found in ELB. Chrysophytes are found in all non-moat POM, and are most common in the middle depths (15 - $30 \mathrm{~m})$. Chrysophyte cysts are abundant and diatoms are common in sediment trap samples from ELB. Some diatom species are found only in the sediment trap material.

\subsection{West Lake Bonney}

The biota of West Lake Bonney are shown in Table 4 and illustrated on Figures 3 and 4. WLB is most similar to LF. Diatoms are rare in WLB, being found in only three samples (moat SP POM, moat SD BOM, and sediment trap). The distinction between the stream proximal and stream distal locations is striking. Both samples have six species, with only two in common. The SP POM sample contains the diatom, Hantzschiaamphioxys, which is associated with wet soil on the margins of streams. The sediment trap assemblage is similar to that of the SD sample. No chrysophytes were found in WLB.

Two depths are particularly noteworthy in the WLB material. Euhedral aragonite crystals dominate the $35 \mathrm{~m}$ BOM sample. Aragonite was identified on the basis of chemical composition as determined by EDS, as well as crystal morphology. Only fragmentary, single crystals were observed in other samples. The $14 \mathrm{~m}$ POM sample is dominated by a single type of organic-walled, unidentified sac-like body. Except for material collected in sediment traps, diatoms were only found in the moat samples of WLB.

\section{Discussion}

Visual analysis of organic matter via SEM reveals no patterns in the distribution or relative abundances of diatom and chrysophytetaxa across Taylor Valley lakes. Instead, each lake has unique assemblages. Furthermore, no patterns of organismal distribution are seen within or between habitat zones in any given lake. Diatoms are found in all four lakes; however, their distributions, relative proportions, and species assemblages show no consistent patterns, nor are the distributions and abundances of individual taxa similar across the lakes. Lawson et al. [4] describe similarities in the $\delta^{13} \mathrm{C}$ of LH and LF as well as similarities between ELB and WLB. These similarities 
Table 1. Lake Fryxell biota. This table shows the distribution of taxa in LF. Abbreviations are as given in Table 1. Question marks in the data table represent tentative identifications in samples where clean, whole frustules could not be found.

\begin{tabular}{|c|c|c|c|c|c|c|c|c|c|c|c|c|c|}
\hline & POM & POM & POM & POM & POM & POM & POM & BOM & $\mathrm{BOM}$ & $\mathrm{BOM}$ & BOM & BOM & $\mathrm{BOM}$ \\
\hline Species/Type & $\begin{array}{c}\text { Moat } \\
\text { SP }\end{array}$ & $\begin{array}{l}\text { Moat } \\
\text { SD }\end{array}$ & $6 \mathrm{~m}$ & $9 \mathrm{~m}$ & $11 \mathrm{~m}$ & $17 \mathrm{~m}$ & $18 \mathrm{~m}$ & $\begin{array}{l}\text { Moat } \\
\text { SP }\end{array}$ & $\begin{array}{c}\text { Moat } \\
\text { SD }\end{array}$ & $6.4 \mathrm{~m}$ & $\mathrm{SD} 8 \mathrm{~m}$ & $\begin{array}{c}\mathrm{SP} \\
16.5 \mathrm{~m}\end{array}$ & $18.5 \mathrm{~m}$ \\
\hline
\end{tabular}

Achnanthestaylorensis

Craticulamolestiformus

Diadesmiscontenta $v$. parallela

Fallacianaumannii

Gomphonema spp.

Hantzschiaabundans

Hantzschiaamphioxys

Hantzschiaspp 2

Luticolagaussii

Luticolamuticopsis $v$. reducta

Luticolamutica

Marine fragments

Melosiracharcotii

Muelleriameridionalis

Muelleriaperaustralis

$\mathrm{R}$

Naviculacincta

Naviculashackeltoni

Nitzschiawestii

Pinnularia borealis

Pinnulariadeltaica

U

Pinnulariaquaternaria

U

$\mathrm{R}$

$\mathrm{R}$

Psammothidiumchlidanos

Psammothidiumgermainii

Stauroneislatistauros

Stauronellaconstricta

Chrysophyte 1

Chrysophyte 2

Chrysophyte 3

Chrysophyte 5

Chrysophyte 6

Chrysophyte 7

Precipitates

U (Gypsum) R (Gypsum) 


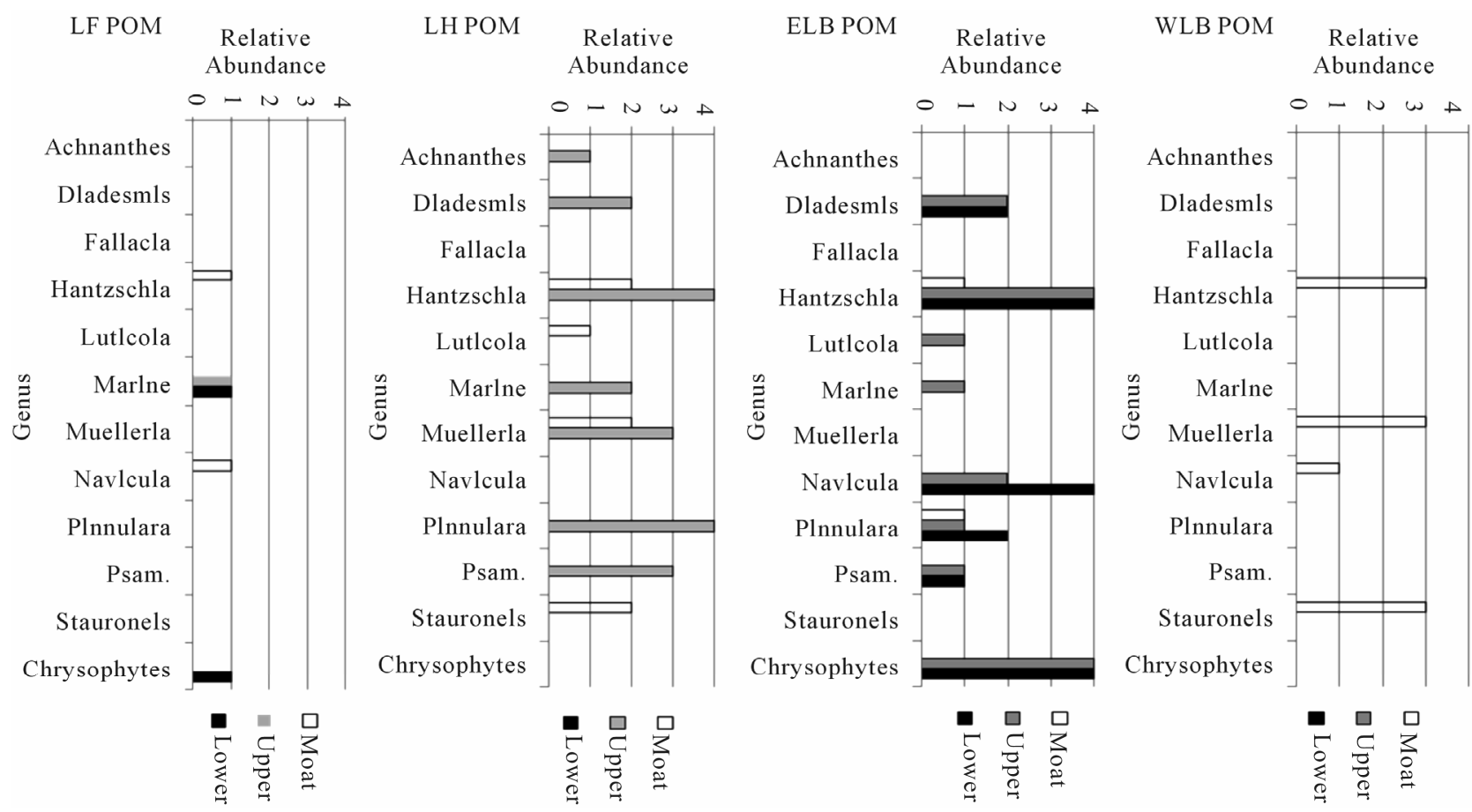

Figure 3. Distribution of biota in POM of Taylor Valley Lakes. This graph shows depth zones of particulate organic matter (Moat, Upper, and Lower water column) for selected taxa. Any genus of diatom or chrysophytemorphotype that was present in only one sample was withheld. Diatoms are shown on the genus level; species data are presented in Tables 1-4. Abundances are relative, from 4 (abundant) to 1 (rare). The water column of Lake Hoare is uniformly considered as upper. The abbreviation Psam. is used for the genus Psammothidium.
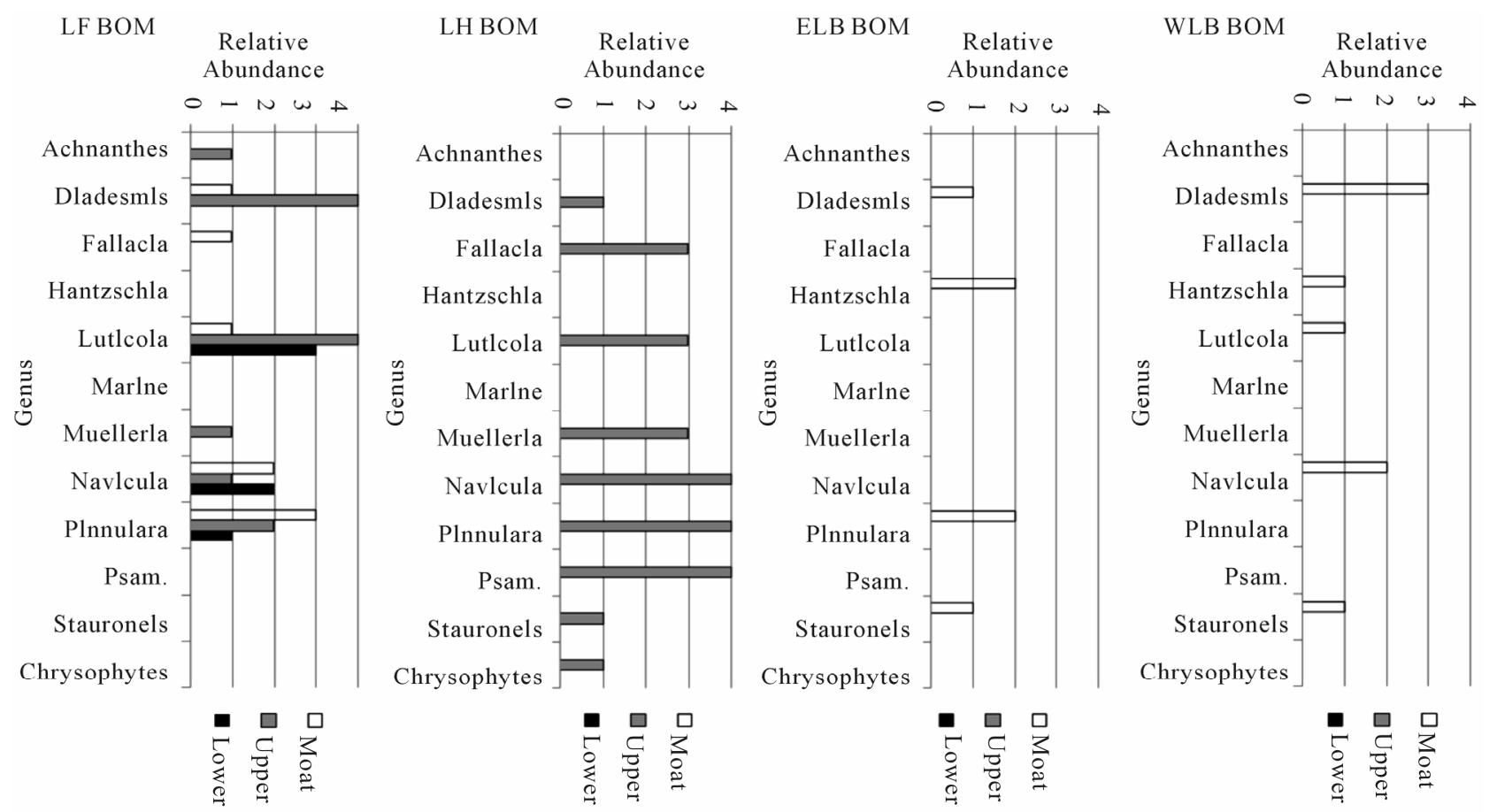

Figure 4. Distribution of biota in BOM of Taylor Valley Lakes. This graph shows depth zones of benthic organic matter (Moat, Upper, and Lower water column) for selected taxa.Any genus of diatom or chrysophytemorphotype that was present in only one sample was withheld. Diatoms are shown on the genus level; species data are presented in Tables 1-4. Abundances are relative, from 4 (abundant) to 1 (rare). The water column of Lake Hoare is uniformly considered as upper. The abbreviation Psam. is used for the genus Psammothidium. 
Table 2. Lake Hoare biota. This table shows the distribution of taxa in LH. Abbreviations are as given in Table 1. Question marks in the data table represent tentative identifications in samples where clean, whole frustules could not be found.

\begin{tabular}{|c|c|c|c|c|c|c|c|c|c|}
\hline \multirow{2}{*}{ Species/Type } & POM & POM & $\mathrm{POM}$ & POM & BOM & BOM & $\mathrm{BOM}$ & BOM & BOM \\
\hline & Moat SP & $6 \mathrm{~m}$ & $10 \mathrm{~m}$ & $20 \mathrm{~m}$ & Moat & $7 \mathrm{~m}$ & $10 \mathrm{~m}$ & $22 \mathrm{~m}$ & $26 \mathrm{~m}$ \\
\hline
\end{tabular}

Achnanthestaylorensis

$\mathrm{R}$

$\mathrm{R}$

Craticulamolestiformus

Diadesmiscontenta v. parallela

$\mathrm{R}$

U

Fallacianaumannii

Gomphonema spp.

Hantzschiaabundans

$\mathrm{U}$

Hantzschiaamphioxys

Hantzschiaspp 2

Luticolagaussii

$\mathrm{R}$

Luticolamuticopsis $v$. reducta

Luticolamutica

Marine fragments

Melosiracharcotii

Muelleriameridionalis

Muelleriaperaustralis

Naviculacincta

Naviculagregaria

Naviculashackeltoni

Nitzschiawestii

Pinnularia borealis

Pinnulariadeltaica

Pinnulariaquaternaria

Psammothidiumchlidanos

Psammothidiumgermainii

Stauroneislatistauros

Stauronellaconstricta

Chrysophyte 1

Chrysophyte 2

Chrysophyte 3

Chrysophyte 5

Chrysophyte 6

Chrysophyte 7

U

R U

U

C

C

$\mathrm{R}$

C

U

$\mathrm{R}$

$\mathrm{R}$

$?$

U

A

$\mathrm{R}$

$\mathrm{R}$

A

A
U

C
A $\quad \mathrm{R} \quad \mathrm{R}$

Precipitates 
Table 3. East Lake Bonney biota. This table shows the distribution of taxa in ELB. Abbreviations are as given in Table 1. Question marks in the data table represent tentative identifications in samples where clean, whole frustules could not be found.

\begin{tabular}{ccccccccccc}
\hline \multirow{2}{*}{ Species/Type } & POM & POM & POM & POM & POM & \multirow{2}{*}{ POM } & BOM & BOM & Sed Trap \\
\cline { 2 - 8 } & Moat SP & $6 \mathrm{~m}$ & $15 \mathrm{~m}$ & $22 \mathrm{~m}$ & $30 \mathrm{~m}$ & $38 \mathrm{~m}$ & Moat & 37.5 & $35 \mathrm{~m}$ \\
\hline
\end{tabular}

Achnanthestaylorensis

Craticulamolestiformus

Diadesmiscontenta v. parallela

Fallacianaumannii

Gomphonema spp.

R

Hantzschiaabundans

R

R

Hantzschiaamphioxys

A

A

A

$\mathrm{R}$

Hantzschiaspp 2

Luticolagaussii

Luticolamuticopsis v. reducta

Luticolamutica

Marine fragments

Melosiracharcotii

Muelleriameridionalis

Muelleriaperaustralis

Naviculacincta

$?$

$\mathrm{R}$

Naviculagregaria

U

A

C

Naviculashackeltoni

Nitzschiawestii

Pinnularia borealis

Pinnulariadeltaica

$\mathrm{R}$

Pinnulariaquaternaria

$\mathrm{R}$ $\mathrm{R}$

$?$

$\mathrm{R}$

Psammothidiumchlidanos

Psammothidiumgermainii

Stauroneislatistauros

Stauronellaconstricta

Chrysophyte 1

C

C

U

A

Chrysophyte 2

$\mathrm{U} / \mathrm{R}$

Chrysophyte 3

R

Chrysophyte 5

R

Chrysophyte 6 $\mathrm{R}$

Chrysophyte 7

Precipitates

R (Calcite and Aragonite) 
Table 4. West Lake Bonney biota this table shows the distribution of taxa in WLB. Abbreviations are as given in Table 1.

\begin{tabular}{lcccccccccccc}
\hline \multirow{2}{*}{ Species/Type } & POM & POM & POM & POM & BOM & BOM & BOM & BOM & BOM & BOM & Sed Trap \\
\cline { 2 - 11 } & Moat SP & $6 \mathrm{~m}$ & $14 \mathrm{~m}$ & $40 \mathrm{~m}$ & Moat SP & Moat SD & $18.5 \mathrm{~m}$ & $28 \mathrm{~m}$ & $35 \mathrm{~m}$ & $39 \mathrm{~m}$ & $35 \mathrm{~m}$
\end{tabular}

Achnanthestaylorensis

Craticulamolestiformus

$\mathrm{R}$

Diadesmiscontenta $v$. parallela

Fallacianaumannii

Gomphonema spp.

Hantzschiaabundans

Hantzschiaamphioxys

Hantzschiaspp 2

Luticolagaussii

Luticolamuticopsis v. reducta

Luticolamutica

Marine fragments

Melosiracharcotii

Muelleriameridionalis

Muelleriaperaustralis

Naviculacincta

Naviculagregaria

Naviculashackeltoni

Nitzschiawestii

Pinnularia borealis

Pinnulariadeltaica

Pinnulariaquaternaria

Psammothidiumchlidanos

Psammothidiumgermainii

Stauroneislatistauros

Stauronellaconstricta

Chrysophyte 1

Chrysophyte 2

Chrysophyte 3

Chrysophyte 5

Chrysophyte 6

Chrysophyte 7

Precipitates A (Aragonite) 
are related to physical limnological characteristics, namely steepness of bed walls. This study shows similarities between LH and ELB as well as LF and WLB. The change in dichotomy between these two studies demonstrates that the $\delta^{13} \mathrm{C}$ pattern observed in TV lakes is decoupled from biological community composition.

In surface sediments of all four lakes there exists no gradient of change in community composition. There exists no definable "BOM/sediment assemblage" or "POM/ water column assemblage". Each lake is unique with respect to the differences between the sediments and water column. Boundaries between biological zones are sharp, as observed by other authors $[14,15]$. This is contrary to expectations, given that $\delta^{13} \mathrm{C}$ becomes gradually more depleted with depth, reaching values of $-35 \%$ to $-40 \%$ in the BOM of all four Taylor Valley lakes [4]. This pattern of carbon isotope depletion is attributed by Lawson et al. [4] as being derived from the ratio of in situ BOM growth to POM deposition, with OM from the deepest parts of all four lakes being completely POM sourced. $\delta^{13} \mathrm{C}$ from $\mathrm{OM}$ in the photic zone in Lake Hoare is controlled by a diffusion limitation [21]. This limitation is likely present in all lakes, controlling the $\delta^{13} \mathrm{C}$ of photic zone BOM.

LH and ELB both have diverse and abundant diatoms. However, the specific species found within each lake are not comparable. Fifteen diatom species were observed in LH and 17 in ELB. Of those, only ten are shared. Their apparent relative abundances are different in each lake, although the sediment collection and processing scheme make abundance data suspect. ELB also contains marine diatom fragments where LH does not. The presence of these diatoms implies sediment transport from McMurdo Sound. The difference in chrysophyte distribution is striking. The ELB sediment trap material contains thousands of chrysophte cysts per gram of sediment. No other single sample contains even a tenth of that number, and outside of ELB no single sample contains more than two. It is unreasonable to suspect that such a large volume of chrysophyte cysts could be transported within the Valleys and not show a more even distribution. Therefore chrysophytes in the BOM and sediment trap material of ELB are interpreted to be autochthonous. In samples containing only one or two cysts, chrysophytes are interpreted as transported. The POM of nearly all depths in ELB contains abundant Hantzschiaamphioxys, a moist soil diatom associated with stream margins. POM transects were collected during the "flood year" when stream input to TV lakes was greatly increased, and moats were considerably larger [4]. These diatoms are interpreted as having been moved into the lakes by increased stream flow during the flood year. Their presence in such large numbers in the water column over a single season makes preservation in the sediment in a single layer more likely.
Hantzschiaamphioxys was not noted in the BOM of ELB because BOM samples were taken before the flood year. The lack of large numbers of $H$. amphioxys in other lakes attests to the basin-specific nature of deposition in TV lakes.

LF and WLB both have few diatoms. LF has common diatoms in some BOM samples, and is nearly barren in others. WLB has few diatoms in all BOM samples. Both lakes have few chrysophytes, which are interpreted as transported. Once again, the diatoms are from different species and have different distributions; fifteen diatom species are found in LF, 11 are found in WLB and only 7 are shared. Those diatoms that are shared between the two lakes have different abundances and distributions within the lakes. Within LF, more diatoms are found in the upper water sediments than the lower. Aragonite was found in one sample ( $35 \mathrm{~m} \mathrm{BOM})$ in WLB. Aragonite was not found in the sediment trap material from $35 \mathrm{~m}$, so it is interpreted as precipitated in place at $35 \mathrm{~m}$ depth rather than falling out from above. Also exclusive to WLB were unidentified sac-like bodies. They were found in the POM at 14 meters, associated with the chemocline. Their restricted distribution suggests that they may be living at the chemocline, suspended by the density stratification. These objects resemble single, dehydrated cells, and average $8 \mu \mathrm{m}$ across. When left to prolonged (90 120s) EDS beam exposure, they ablate and crack. All EDS analyses of these bodies yield different results, but carbon is always included in the element list. This, along with the round cell shape, implies that these unknowns at $14 \mathrm{~m}$ water depth are organic-walled bodies. Samples from both WLB and LF were found without any particulate organic matter. These samples did contain organic carbon coating the filters. It is highly unlikely that the observed organic coating formed secondarily after sampling, as the filters were sterilized and freeze-dried.

Lake exterior biological influences are also different in each lake. It has been proposed that streams influence the lakes to a distance of at least six meters away from their input at the moat [4]. The data presented here support these observations. However, it is possible for a single event, e.g. a flood, to carry material from streams deeper into a lake. Evidence for stream influence comes from the link between stream proximal and moat samples. In Lake Fryxell, diatoms were found in the stream proximal, but not stream distal samples. Some of the same diatoms were found in Huey Creek, which drains into Fryxell. A similar situation is seen with East Lake Bonney and Lake Hoare. In WLB, the stream-edge associated diatom Hantzschiaamphioxys is seen in the moat SP POM sample.

\section{Conclusions}

The carbon isotopic patterns found by Lawson et al. [4] 
are not caused by community composition; each lake shows a different set of species in different relative frequencies and distributions. Legacy nutrients from past lakes dominate the $\delta^{13} \mathrm{C}$ signals of TV lakes and act as the primary nutrient source for organisms carried into the lakes by eolian transport, while ecological barriers provide the dominant control over the distribution of biology within TV Lakes. Transport is a greater barrier to colonization than ecological conditions of the prospective site to be colonized, thus not all suitable habitats have been colonized by all capable species. However, the influence of modern processes and transport of OM can be seen in Taylor Valley lakes. Diatoms found in sediment traps are different from those seen in the water column and sediments, reflecting transport to the site. The direct influence of stream input can be seen in the shallow samples from all four lakes. Diatoms characteristic of streams are found in the moat and shallow under-ice benthic sediments. This is expected, as a $\delta^{13} \mathrm{C}$ link between streams and moat/shallow under-ice areas has been documented previously [4]. Furthermore, the influence of streams on TV lakes is demonstrated by the presence of the diatom genus Hantzschia, whichwas found in all sampled streams and in the shallow samples in all lakes.

Sediment cores from TV lakes must be interpreted with caution. Benthic material in perennially ice-covered lakes represents both autochthonous and allochthonous material, and differentiating between the two may prove difficult. Therefore, the preserved community composition within a core will not reflect the depth at which a core is collected and interpretation may be limited to a basin-wide overview of species. Rather, changes in assemblage demonstrated in cores from TV lakes likely stem to changes in transport regime. Due to the heterogeneous nature of sediment deposition in Dry Valley lakes several cores collected in close association would help to insure that a more complete ecological overview is provided. Organisms preserved in cores have the capability to record single events, such as floods. When studying modern lake conditions, each lake must be sampled individually. No one lake can be used as a biological model for the others.

Only the broadest of generalizations can be applied to the distribution of diatoms and chrysophyte cysts of Taylor Valley lakes as a group: Diatoms are found in all four lakes. All four lakes have variable distributions of taxa in the sediments and water column. All four lakes are subject to differing amounts of various exterior environmental influences. The specific species found, distributions of those species, and relative abundance within an assemblage are highly variable in all four Taylor Valley lakes studied. As a further complication, a species may be autochthonous to one lake and allochthonous to another. Visual examination of the preservation condi- tions of specimens can help to determine which case is appropriate for each sample taken. Whole diatom frustules and colonial diatom chains are likely found in situ, where single or fragmentary valves have likely been transported. In the future, visual examinations of recovered sediment or other particulate material should accompany chemical/isotopic measurements as the two are decoupled. This will provide a more complete picture of the biology of perennially ice-covered lakes.

\section{Acknowledgements}

This research was carried out under the auspices of the McMurdo Long Term Ecological Research site (NSF grant number ANT0423595). We would like to thank everyone who has provided field and lab support. Bob Bailey, Jay Zhou, and Jack Gibbons have kept the scopes up and working beautifully. For help in the field, we would like to thank Miroljub Medved especially, and also the rest of the MCM LTER team.

\section{REFERENCES}

[1] P. T. Doran, J. Priscu, W. B. Lyons, J. Walsh, A. G. Fountian, D. M. McKnight, D. Moorhead, R. Virginia, D. Wall, G. Clow, C. Fritsen, C. McKay and A. Parsons, "Antarctic Climate Cooling and Terrestrial Ecosystem Response," Nature, Vol. 415, No. 6871, 2004, pp. 517520. doi:10.1038/nature710

[2] D. Moorhead, P. T. Doran, A. Fountain, W. B. Lyons, D. M. McKnight, J. Priscu, R. Virginia and D. Wall, "Ecological Legacies: Impacts on Ecosystems of the McMurdo Dry Valleys," BioScience, Vol. 48, 1999, pp. 1009-1021. doi:10.2307/1313734

[3] D. M. McKnight, D. Niyogi, S. Alger, A. Bomblies, P. Conovitz and C. Tate, "Dry Valley Streams in Antarctica: Ecosystems Waiting for Water," Bioscience, Vol. 49, 1999, pp. 985-995. doi:10.2307/1313732

[4] J. Lawson, P. T. Doran, F. Kenig, D. Des Marais and J. Priscu, "Stable Carbon and Nitrogen Isotopic Composition of Benthic and Pelagic Organic Matter in Lakes of the McMurdo Dry Valleys, Antarctica," Aquatic Geochemistry, Vol. 10, No. 3, 2004, pp. 269-301. doi:10.1007/s10498-004-2262-2

[5] G. Denton and T. Hughes, "Reconstruction of the Ross Ice Drainage System, Antarctica, at the Last Glacial Maximum," Geografiska Annaler, Vol. 82A, No. 2-3, 2000, pp. 143-166. doi:10.1111/1468-0459.00120

[6] G. Denton and D. Marchant, "The Geologic Basis for a Reconstruction of Grounded Ice in McMurdo Sound, Antarctica, at the Last Glacial Maximum," Geografiska Annaler, Vol. 82A, No. 2-3, 2000, pp. 167-211. doi:10.1111/1468-0459.00121

[7] B. Hall, H. Denton and C. Hendy, "Evidence from Taylor Valley for a Grounded Ice Sheet in the Ross Sea, Antarctica," Geografiska Annaler, Vol. 82A, No. 2-3, 2000, pp. 275-303. doi:10.1111/1468-0459.00126 
[8] C. Hendy, "Late Quaternary Lakes in the McMurdo Sound Region of Antarctica," Geografiska Annaler, Vol. 82A, No. 2-3, 2000, pp. 411-432. doi:10.1111/1468-0459.00131

[9] M. Burkins, R. Virginia, C. Chamberlain and D. Wall, "Origin and Distribution of Soil Organic Matter in Taylor Valley, Antarctica," Ecology, Vol. 81, 2000, pp. 237-239. doi:10.1890/0012-9658(2000)081[2377:OADOSO]2.0.C $\underline{\mathrm{O} ; 2}$

[10] R. H. Spigel and J. Priscu, "Physical Limnology of the McMurdo Dry Valley lakes," In: J. Priscu, Ed., Ecosystem Dynamics in a Polar Desert: The McMurdo Dry Valleys, Antarctica, American Geophysical Union, 2000, pp. 153-187.

[11] R. Wharton Jr., C. McKay, B. Parker and G. Simmons Jr., "Oxygen Budget of a Perennially Ice-Covered Antarctic Dry Valley Lake," Limnology and Oceanography, Vol. 31, 1986, pp. 437-443. doi:10.4319/1o.1986.31.2.0437

[12] J. Priscu, C. Fritsen, E. Adams, S. Giovannoni, H. Paerl, C. McKay, P. T. Doran, D. Gordon, B. Lanoi and J. Pinckney, "Perennial Antarctic Lake Ice: An Oasis for Life in a Polar Desert," Science, Vol. 280, No. 5372, 1998, pp. 2095-2098. doi:10.1126/science.280.5372.2095

[13] S. Squyers, D. Anderson, S. Nedell and R. Wharton, "Lake Hoare, Antarctica: Sedimentation through a Thick Perennial Ice Cover," Sedimentology, Vol. 38, No. 2, 1991, pp. 363-379. doi:10.1111/j.1365-3091.1991.tb01265.x

[14] I. Hawes and A.-M. Schwarz, "Absorbtion and Utilization of Irradiance by Cyanobacterial Mats in Two Ice-Covered Antarctic Lakes with Contrasting Light Climates," Journal of Phycology, Vol. 37, No. 1, 2000, pp. 5-15. doi:10.1046/j.1529-8817.1999.014012005.x
[15] I. Hawes and A.-M. Schwarz, "Photosynthesis in and Extreme Shade Environment: Benthic Microbial Mats from Lake Hoare, a Permanently Ice-Covered Antarctic Lake," Journal of Phycology, Vol. 35, No. 3, 1999, pp. 448-459. doi:10.1046/j.1529-8817.1999.3530448.x

[16] S. Spaulding, D. M. McKnight, E. Stoermer and P. T. Doran, "Diatoms in Sediments of Perennially Ice-Covered Lake Hoare, and Implications for Interpreting Lake History in the McMurdo Dry Valleys of Antarctica," Journal of Paleolimnology, Vol. 17, No. 4, 1997, pp. 403-420. doi:10.1023/A:1007931329881

[17] P. T. Doran, D. M. McKnight, C. Jaros, A. G. Fountain, T. H. Nylen, C. P. McKay and D. L. Moorhead, "Hydrologic Response to Extreme Warm and Cold Summers in the McMurdo Dry Valleys, East Antarctica," Antarctic Science, Vol. 20, No. 5, 2008, pp. 499-509. doi:10.1017/S0954102008001272

[18] J. Priscu, C. Wolf, C. Takacs, C. Fritsen, J. LaybournParry, E. Roberts, B. Sattler and W. B. Lyons, "Carbon Transformations in a Perennially Ice-Covered Antarctic Lake," BioScience, Vol. 48, 1999, pp. 997-1008. doi: $10.2307 / 1313733$

[19] A. Wilkinson, B. Zeeb and J. Smol, "Atlas of Chrysophycean Cysts, Volume II," Kluwer Academic Publishers, Dordrect, 2001.

[20] K. Duff, B. Zeeb and J. Smol, "Atlas of Chryosphycean Cysts,” Kluwer Academic Publishers, Dordrect, 1995.

[21] P. T. Doran, R. Wharton, D. Des Marais and C. McKay, "Antarctic Paleolake Sediments and the Search for Extinct Life on Mars," Journal of Geophysical ResearchPlanets, Vol. 103, 1998, pp. 28481-28493. doi:10.1029/98JE01713 